(C) 1990 ISIJ

(1)IIIIIIIIII

論 文 微量すず被覆を施したクロムめっき鋼板の特性

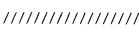

\author{
清水信義 ${ }^{*} \cdot$ 国繁文男 ${ }^{*} \cdot$ 藤本輝則 ${ }^{*} \cdot$ 乾 恒夫 $^{* 2}$
}

\title{
Characteristics of Tin Flash-coated Chromium Plated Steel Sheet
}

Nobuyoshi Shimizu, Fumio Kunishige, Terunori Fujimoto and Tsuneo InUI

Synopsis :

Tin flash-coated chromium plated steel sheet for a welded can has been developed using a low concentrated stannous sulfate solution. The performance of this sheet was discussed from the point of the coating weight and structure.

The results are as follows:

1) An uniform and well-adhered tin layer can be deposited on the chromium layer by a low concentrated stannous sulfate solution.

2) The chromium layer inhibits the iron-tin alloy reaction during the lacquer curing and leaves much tin unalloyed. The residual metallic tin coating above $0.1 \mathrm{~g} / \mathrm{m}^{2}$ in weight can considerably reduce the electric contact resistance.

3) This steel sheet shows good weldability, high corrosion resistance, good lacquer adhesion and high abrasion resistance due to the combination of metallic tin layer with a chromium plated steel sheet.

Key words : weldability; corrosion resistance; lacquer adhesion; abrasion; electrodeposition ; alloy formation; surface analysis.

\section{1. 緒言}

ワイヤーシーム溶接製缺法がスイスのスードロニック 社により開発されて以来，接合部の信頼性の高い溶接待 は一般食品および飲料用容器に国内外で広く普及してき た.特にはんだ中の鉛問題が米国で取り上げられて以来, 1981 年頃から溶接行の牛産量は急増し, 食行中に占め るはんだ行の割合が急減した，浴接们の生産量が多くな るにつれ，ぶりきよりも安価な溶接金用材料が望まれる ようになり，下地層として微量ニッケルを施した低すず めっき鋼板 (LTSという) が開発され実用に供されて いる ${ }^{1)-4)}$.この LTS は $0.8 \mathrm{~g} / \mathrm{m}^{2}$ 程度のすずを使用し ており経済的メリットが少ないため, 近年, さらに安価 な材料の開発が望まれている。一方, 安価な容器用材料 として長年使われている電解クロム酸処理鋼板 （TFS-CTという）は最表層のクロム水和酸化物皮膜の 導電性が極めて悪いため, 高い気密性と美麗な外観を必 要とする飲料缶分野の溶接缶には用いられていない.

そこで, 種々検討した結果, LTSより低コストでか
つ溶接性に優れた材料として，鋼板上に金属クロム層， 微量すず層, さらにクロム水和酸化物層を主体とするク ロム層を形成させた表面処理鋼板を開発した ${ }^{5)}$. 本材料 は微量すず層と鋼板の間に薄い金属クロム層を存在させ ることにより塗装焼付けの加熱を施してもすずの命金化 を抑制することができ，したがって，クロム水和酸化物 皮膜の下層に存在する低融点で采らかい 0.1-0.2 $\mathrm{g} / \mathrm{m}^{2}$ 程度の微量のすず層の働きで通電を谷易にすることがで きるため溶接性に極めて優れている6). また,この微量 すずを被覆したクロムめっき鋼权は TFS-CT の皮膜構 造を基本としているため耐食性や涂料密着性にも優れて いる.

本報では本材料の皮膜構造と浴接性, 塗料密着性, 酎 食性などの特性との関連を調査し，特性を支配する要因 について検討した結果を報告する.

\section{2. 実 験 方 法}

\section{$2 \cdot 1$ 供試材の作成}

板厚 $0.22 \mathrm{~mm}$ の $\mathrm{Al}$ キルド冷延鋼板を通常のアルカ 昭和 61 年 10 月本会講演大会にて発表 平成元年 5 月 11 日受付 (Received May 11, 1989)

* 東洋鋼鈑(株)技術研究所 (Technical Research Laboratory, Toyo Kohan Co., Ltd., 1296-1 Higashitoyoi Kudamatsu 744)

*2 東洋鋼鉝(株)技術研究所 T博（Technical Research Laboratory, Toyo Kohan Co., Ltd.) 
Table 1. Plating conditions.

\begin{tabular}{c|l|c}
\hline & Bath composition $(\mathrm{g} / \mathrm{l})$ & Electrolysis conditions \\
\hline \multirow{2}{*}{ Metallic chromium plating } & Chromic acid $: 150$ & Temperature $: 60^{\circ} \mathrm{C}$ \\
& $\begin{array}{l}\text { Sodium silicofluoride }: 5 \\
\text { Culfuric acid }: 0.8\end{array}$ & \\
\hline \multirow{2}{*}{ Tin flash coating } & Stannous sulfate $: 3-60$ & Temperature $: 40^{\circ} \mathrm{C}$ \\
& $\begin{array}{l}\text { Sulfuric acid }: 5-30 \\
\text { Ethoxylated } \alpha \text {-naphthol }: 5\end{array}$ & Current density $: 20 \mathrm{~A} / \mathrm{dm}^{2}$ \\
\hline Post-treatment & $\begin{array}{l}\text { Chromic acid }: 30 \\
\text { Sulfuric acid }: 0-0.5\end{array}$ & $\begin{array}{c}\text { Temperature }: 50^{\circ} \mathrm{C} \\
\text { Current density }: 20-50 \mathrm{~A} / \mathrm{dm}^{2}\end{array}$ \\
\hline
\end{tabular}

リ電解脱脂，硫酸酸洗後に Table 1 に示した浴組成と 電解条件でク口ムめっき, すずめっき, 後処理の順に処 理して供武材を作成した。

また，製造ラインで作成した試料について，溶接試験， 臫食性試験，傷つき性試験などを行った。

また，比較試料として，LTS，すず量 $2.8 \mathrm{~g} / \mathrm{m}^{2}$ のぶ りき, TFS-CT (ふっ化物浴) を使用した。

\section{$2 \cdot 2$ めっき層の分析}

\section{(1) 皮膜量}

湿式分析で定量した標準試料を検量線に用いて, 蛍光 $\mathrm{X}$ 線装置（Rigaku 3064）により供試材の Cr と Snの付 着量を測定した。後処理で生成したクロム水和酸化物量 は $95^{\circ} \mathrm{C}, 300 \mathrm{~g} / \mathrm{l}$ の $\mathrm{NaOH}$ 溶液に $5 \mathrm{~s}$ 浸漬前後の $\mathrm{Cr}$ 量 の差から求めた $\mathrm{Cr}$ 量で表した。後処理で生成した金属 クロム量は微量であり, また, クロムめっきで生成した 金属クロム量と分別できないため, 便宜上, クロム水和 酸化物中の $\mathrm{Cr}$ 量で後処理皮膜量を表した。

\section{( 2 )表而観祭}

走榃型電子顕微鏡 (SEM, JEOL JSM-840) を用いて 供武材表泊のすずの電着状態を観祭した。

( 3 )めっき穈の被覆性と深さ力的の元素分析

X 線光笔子分光光度計 (XPS, PHI 5100) を用いて構 成元素の強度を測定し各元素の原子比で被覆性を評価し た。ま， Ar ガスた $20 \mathrm{mPa}, 3 \mathrm{kV}, 20 \mathrm{~mA}$ の条件で Ar ガスエッチングをして深さ坫问の各元素の比率を分 析した。

\section{$2 \cdot 3$ 溶接性}

\section{(1) 接触抵抗 $(R c)$ 測定}

金めっきした厚さ $2 \mathrm{~mm}, 100 \mathrm{~mm} \phi$ の釦製回転電極間 に2枚重ねした試験片を $50 \mathrm{kgf} の$ 加川をかけながら 5 $\mathrm{m} / \mathrm{min}$ の速度で移動させ, $5 \mathrm{~A}$ の分電流を印加した時の 抵抗值の斗均值を測定した。試験片は塗装焼付工程での

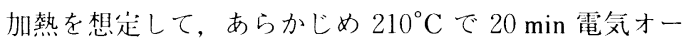
ブン中で加熱した。

( 2 ) 溶接試験

$210^{\circ} \mathrm{C}$ で $20 \mathrm{~min}$ 加熱した試験片を 202 径, $250 \mathrm{ml}$ 缶
の溶接ブランクの大きさに切断し, スードロニックタイ プ溶接機で溶接速度 $32 \mathrm{~m} / \mathrm{min}$, 周波数 $400 \mathrm{~Hz}$, 加压力 $50 \mathrm{kgf}$ の条件で溶接試験を行った。溶接電流上限はスプ ラッシュで評価し, 溶接電流下限はテアー強度で評価し て, 溶接時の 2 次側電流の上限電流と下限電流の差を溶 接可能電流範囲とした。

\section{$2 \cdot 4$ 塗料密着性}

( 1 ) $\mathrm{T}$ ピール剥離試験

供試材を $195^{\circ} \mathrm{C}$ で $10 \mathrm{~min}$ 加熱後, フェノール・エポ

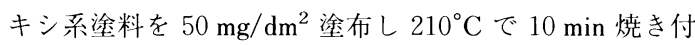
けた。この試験片を $5 \times 100 \mathrm{~mm}$ の大きさに切断して 2 枚重㸚し, 厚さ $100 \mu \mathrm{m}$ のナイロンフィルムを挟んで $200^{\circ} \mathrm{C}$ で $30 \mathrm{~s}$ 加熱圧着した。このようにして作成した 試験片を $90^{\circ} \mathrm{C}$ の $0.4 \%$ クエン酸溶液中に 5 日間浸漬 後, 引張試験機で $\mathrm{T}$ 字型に剝離した時の強度を測定し た。

\section{$2 \cdot 5$ 耐食性}

( 1 )塩水噴霧試験（SST, JIS Z 2371)

供試材を $210^{\circ} \mathrm{C}$ で $10 \mathrm{~min}$ 加熱後 $5 \%$ 食塩水溶液を $1 \mathrm{~h}$ 噴霧し, 発錆の程度を評価した。

( 2 )塗膜下隼食試験 1 (UCC 試験)

クロスカットを入れた塗装試験片を $1.5 \%$ クエン酸 と $1.5 \%$ の食塩を含む $38^{\circ} \mathrm{C}$ の腐食液に 2 週間浸漬し, カット部の腐食幅とブリスターの発生程度を 5 段階に評 価した。

\section{( 3 ) 塗膜下腐食試験 2 (UFC 試験)}

クロスカットを入れた塗装試験片をエリキセンで 5 $\mathrm{mm}$ 張り出した後, $70^{\circ} \mathrm{C} て ゙ 20 \mathrm{~h}, \mathrm{UCC}$ 試験と同じ腐食 液に浸漬した。試験片を洗浄後, 腐食部の浮いた塗膜を セロテープで剥離した時の塗膜剥離面積を测定した。

\section{(4)実缶試験}

塗装した溶接ブランクを午胴部に使用して作成した溶

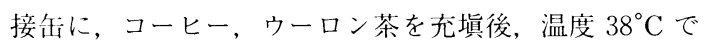
12 か月間保存した。午詰内谷物への金属溶出量は原子 吸光光度計で測定した。 


\section{$2 \cdot 6$ 傷つき性}

2 枚の供試材を切断カエリ面を反対にして重水, 摩擦 係数測定機（HEIDON-14D）にセットした。 $200 \mathrm{~g}$ の荷 重を与えた状態で, $50 \mathrm{~mm} / \mathrm{s}$ の速さで試料を移動させた 時の動摩擦係数の平均值を測定した。また, 溶接機で無 塗装の溶接ブランクを 500 缶連続して通した時の缶内 外面の傷の状態を観察した.

\section{3. 結 果と考察}

\section{$3 \cdot 1$ 金属クロム上のすずの電着条件と析出状態}

硫酸すずを使用して建浴した低濃度すずめっき浴と通 常のぶりき製造に使われているすずめっき浴（フェロス タン浴）を用いて，鋼板上と金属クロム上にすずを電着 した時の金属すずの析出状態を Photo. 1 に示した。鋼 板上にすずを析出する場合は (c)，（d）に見られるよう
にすずめっき浴組成にほとんど依存しない。ところが， 金属クロム上にすずを析出させる場合は，電析で得られ る金属クロム表面には必ずクロム水和酸化物が存在する ため，通常のすずめっき浴を用いた場合は（b）に見ら れるようにすずの均一電着性が悪く密着性も悪い.一方, 低濃度すずめっき浴を用いると多量の水素ガスの発生に より表層のクロム水和酸化物を溶解しながらすずの電着 がおこるため，（a）に見られるようにすずの均一析出が 可能になり密着性も大幅に改善される.すずめっき後に 残存しているクロム水和酸化物量を蛍光 X 線分析装置 やXPS で測定すると（b）ではクロム水和酸化物がす ずめっき後も多量に検出されるのに対して，(a) ではほ とんど検出されなかった. Fig. 1 はすずめっき後の鋼 板表面のすずの被覆性をXPS で測定した時の $\mathrm{Sn} /(\mathrm{Sn}$ $+\mathrm{Cr}$ ）の原子比で評価したものであり, 硫酸すず濃度
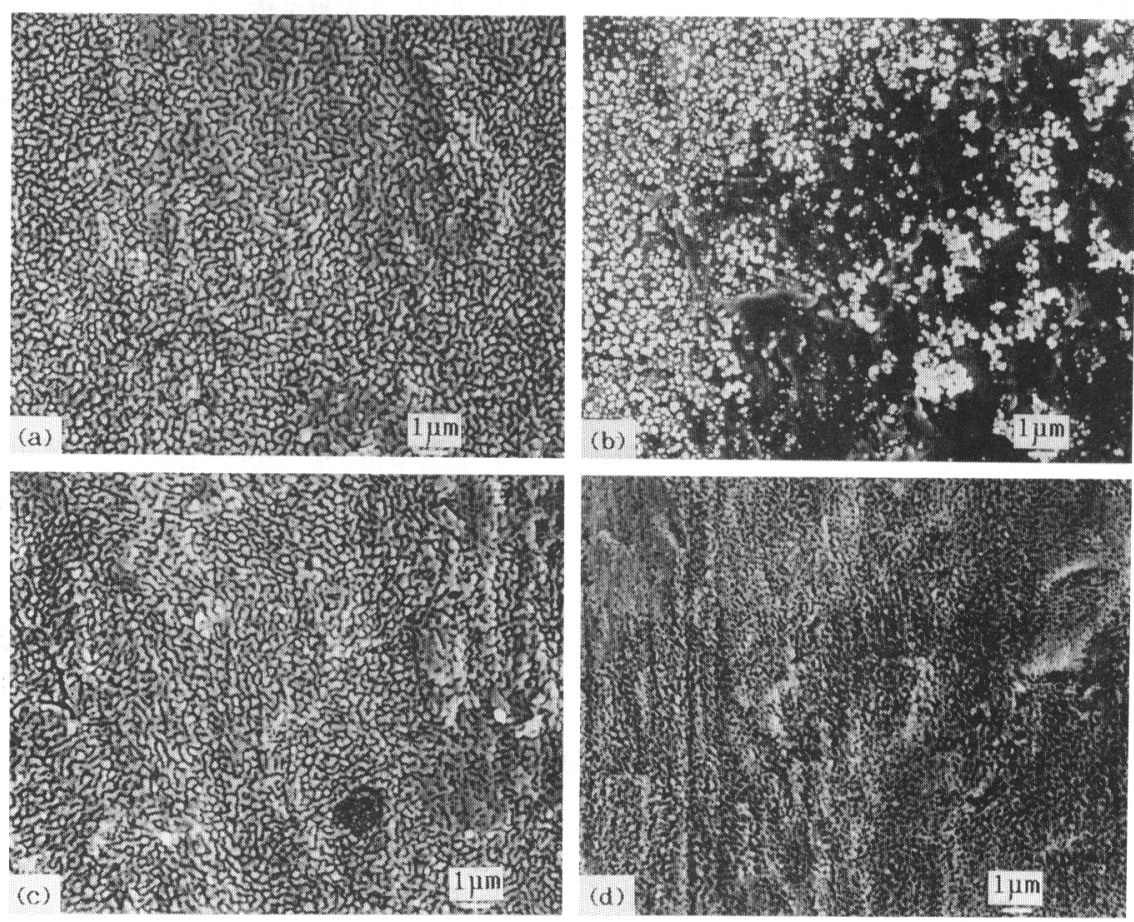

Microstructure of tin coating;

(a) electrolytically deposited on the chromium layer using a low

(Sn: $120 \mathrm{mg} / \mathrm{m}^{2}$ ) concentrated stannous sulfate solution.

(b) electrolytically deposited on the chromium layer using the Ferrostan bath.

(c) electrolytically deposited on the steel surface using a low concentrated stannous sulfate solution.

(d) electrolytically deposited on the steel surface using the Ferrostan bath.

Photo. 1. Microstructure of tin coating electrolytically deposited on chromium layer and steel surface using low concentrated stannous sulfate solution and ferrostan bath. 
が $20 \mathrm{~g} / \mathrm{l}$ 以下の時にすずの被覆㳯が $95 \%$ 以上の被覆性 の良いめっき層が得られる。一う，金属クロム、のすず の析出効率は浴中の硫酸すず濃度に比例して变化するた め, 適度の析出効率と被覆摔を与える硫酸すず濃度は 5-20 g/l となる。このように，均一性と密着性に優れる すずめっき層を金质クロム層上に析出させるには水素発 生を伴う低濃度すずめっき浴の使用が必須であり，陰極 でのすず析出の㲠流効率を約 $50 \%$ 以下に抑える必要が ある。すずめっき層は約 $0.3 \mu \mathrm{m}$ の径で粒状に析出し連

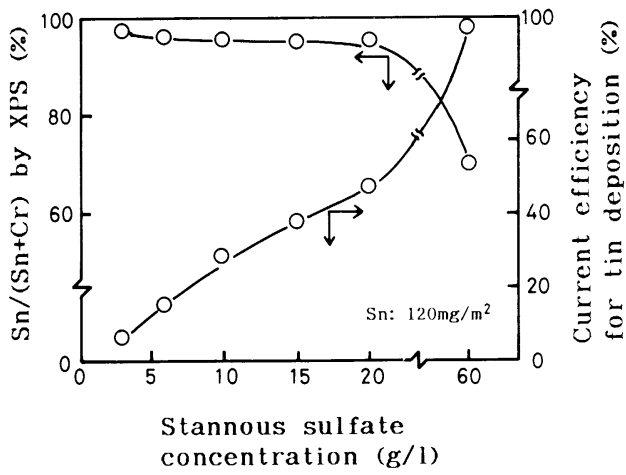

Fig. 1. Effect of stannous sulfate concentration in tin plating bath on coverage of tin coating and current efficiency for tin deposition.
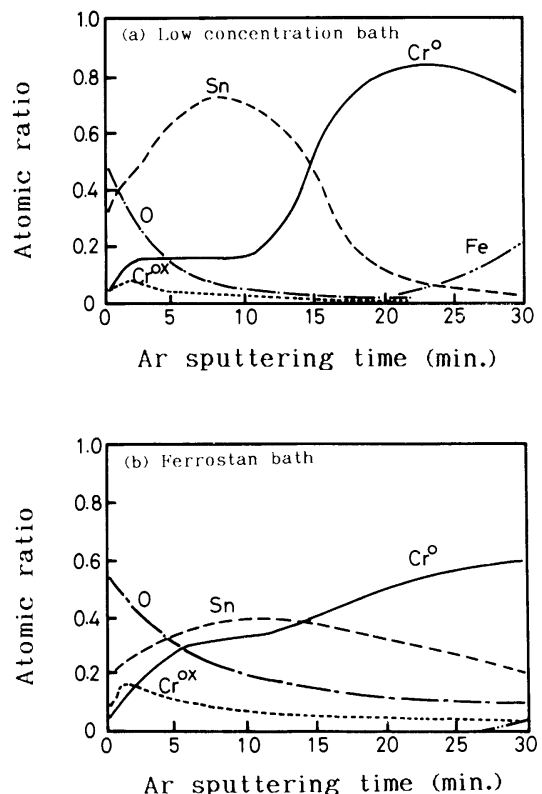

Fig. 2. XPS depth profile of tin flash-coated chromium plated steel sheet.
繶した征をなしている。

Fig. 2(a) は XPSを用いて, 後処理前の供武材の深 さナ问の备元素を分析したものであり鋼板トにクロム めっき層 $(\mathrm{Cr})$ とすずめっき層が積篔されているよう すを艮くあらわしている。 Fig. 2(b) では鋼板上にクロ ムめっき層とすずめっき層が混在しており幽層の境界が 明瞭でない．Fig. 2(b) ではすずの電着が不均一である ため，見掛け上，すず府が金属クロム曾の内部まで存在 しているようなパターンになったものと考えられる。

また，(a）ではすずめっき後に残你するクロム水和酸 化物（汹中 $\mathrm{Cr} \times$ と表示）は少量であるのに対して，(b) では多量のクロム水和酸化物が残存していることがわか る。この袁層に検出さ机るクロム水和酸化物はク口ム めっき時に生成したものであり，Photo１（b）に示した ように金風クロム層上のすずの均・析出を阻斩してい る.

\section{$3 \cdot 2$ 塗装焼付け時の加熱によるすずの合金化挙動}

3 ピース浴接们は溶接部を除いて通常幽面とも塗装さ れる。一部，内面のみ無塗装の用途があるが，いずれに せ上塗装、程での加熱は澼けられない。ぶりきや LTS の場合は溶接前の加熱による令金化仪忍はしばしば，材 料の浴接性に影響を与えることが知られている 曾は浴接性，加工性などに悪影響を与えるため，LTS では例えば微量 Ni めっきによりすずを島状の形態とし て命金化仪応を抑制する方法がとられている。リフロー はすずの全金化伩心を伴うが，その後の全金曽成長を抑 制する働きがある7). しかしながら，すずと鉄の合金化 父応を管军に防ぐためには $200^{\circ} \mathrm{C}$ 付近の温度で加熱し てもすずと令金化しないめっき層が必要である。クロム

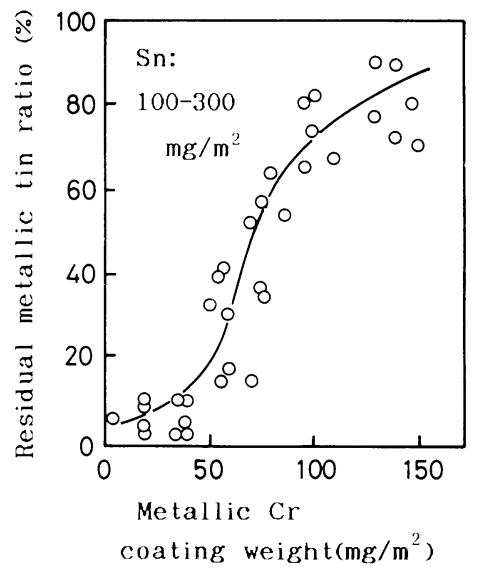

Fig. 3. Effect of metallic chromium coating weight on residual metallic tin ratio after baking. 
めっき層はこの目的にかなっており，被覆性にも優れる 金属であるため好都合である。Fig. 3 は金属ク口ム量 と $210^{\circ} \mathrm{C}$ で $20 \mathrm{~min}$ 加熱後の金属すずの残仔率を示して おり，金属クロムが $100 \mathrm{mg} / \mathrm{m}^{2}$ 以上の時に $70 \%$ 以上の 金属すず残任摔が得られる。 Fig. 4 は高温加熟時の $\mathrm{Sn}-\mathrm{Fe}$ 合金化必忍に対古る金属クロムの抑制作用を頙 葆に示して抢り $250^{\circ} \mathrm{C} て ゙ 20 \mathrm{~min}$ 加熱しても, 全寸ず量 の約 1/3のすずが金風すずのままで任任していた。一 ナ，同条件で加熱したLTSの埸へはほぼ全量が合金化 していた。このように，高温加熱になるほどへ金成長抑 制に対して金属クロムの役割が発揮されることになり， 今後, 高温短時闍焼付塗装が普及すると本材料の特徵が

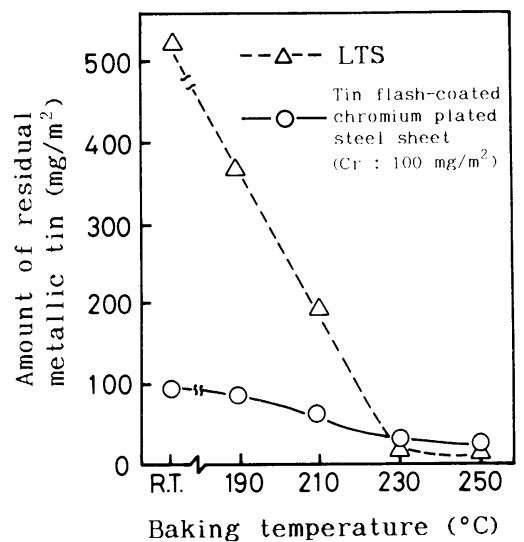

Fig. 4. Effect of baking temperature on amount of residual metallic tin.

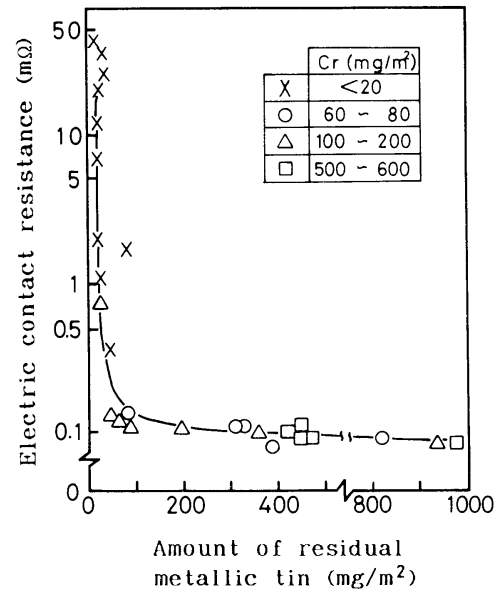

Fig. 5. Relation between amount of residual metallic tin and electric contact resistance after baking.
生かされるものと考えられる。

\section{$3 \cdot 3$ 溶接性}

溶接性に及ぼす寸ず層の役割は浴接時の高温, 高加圧 により瞬時に溶融して金属接触佰子確保し界面の抵抗を 下げることにあると考えられる．Fig. 5 は種々の金属 クロム量とすず量で供試材を作成後 $R c$ 做を測定し, 加 熱後に残仔している金属すず量で整理したものである. 加熱後に約 $0.1 \mathrm{~g} / \mathrm{m}^{2}$ 以上の金属すずがあれば，金属ク ロム量によらず姟起して低い $R c$ 值が得られた。この結 果は,ぶりき, LTS, Ni めっき镃板, TFS-CT な゙の

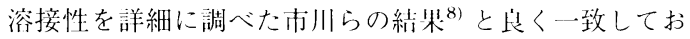
り，金属すずが材料の接触状態を呂好にすることを示し ている.

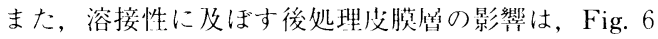
に示すように皮膜量の増加と其に $R c$ 值を上昇させる. 网中にぶりきの $R c$ 值を示したが，本供試材よりも高い 值を示した。本供试材の $R c$ 值がぶりきより低いのは Photo. 1(a) に示したようにすず辟が平消に析虬して いないためと考えられる。一般に金属すず量が少ないほ ど後処理皮膜の影響は顕著にあらわれ，ぶりきの場合は 多量の金属すずが溶接時の加压により端而に移動するた め, 最表層の後処理皮膜は溶接性にほとんど影響を与え ないものと考えられる. Fig. 6 に示した絬果は, 本供 試材のように，わずか $0.1 \mathrm{~g} / \mathrm{m}^{2} の$ 金属すず量でも後処 理皮膜量が $R c$ 值に年える影響を小さくすることができ ることを示している。このように，Rc值で溶接性を予 測することが叮能であり，簡便な方法として哀く使用さ れている9). しかしながら，実際の溶接機による溶接性 を $R c$ 値だけで判断することは危険なため, さらに，供

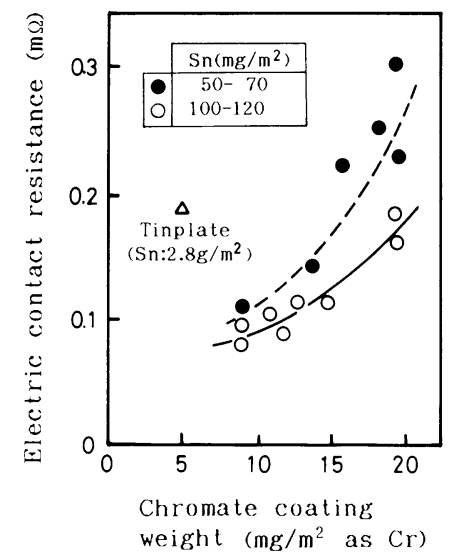

Fig. 6. Effect of chromate coating weight on electric contact resistance after baking. 


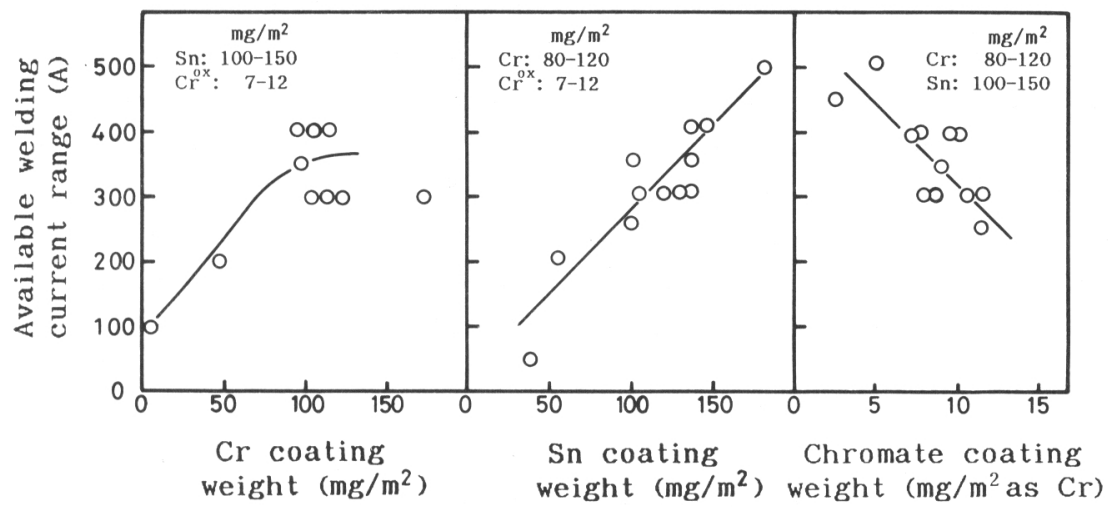

Fig. 7. Effect of coating weights on available welding current range.

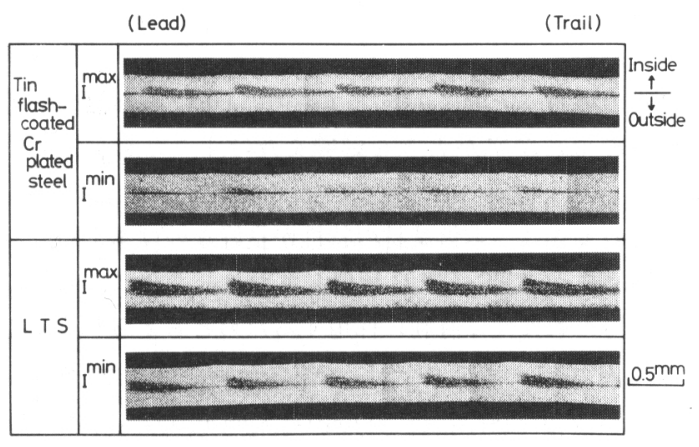

Photo. 2. Longitudinal section of welded seams of tin flash-coated chromium plated steel and LTS.

試材の皮膜量と溶接機で評価した溶接可能電流範囲 (ACR, Available Current Range) の関係を調べた. Fig. 7 に示すように ACR はすず量と後処理皮膜量に大きく 依存し， Rc 值で予測される以上に皮膜量の影響の大き いことがわかった。この理由は $R c$ 值の測定条件が実際 の溶接条件よりも低速, 低温であり, 皮膜量の相違に敏 感でないためと考えられる。すなわち，実際の溶接時に おいては金属すずの溶融と移動により，電極一鋼板間，

鋼板一鋼板間の隙間を金属すずが瞬時に埋めると共に後 処理皮膜の破壊が起こる。したがって, 必要金属すず量 は溶接速度, 加圧力などに依存し, 高速, 低加圧になる ほど必要金属すず量は増加し後処理皮膜量の上限は減少 するものと考えられる.

Photo. 2 に本供試材と LTS の溶接下限電流と溶接上 限電流で溶接した時の溶接部平行断面写真を示した。本 供試材の方が熱影響部の表れかたが小さく, LTSより

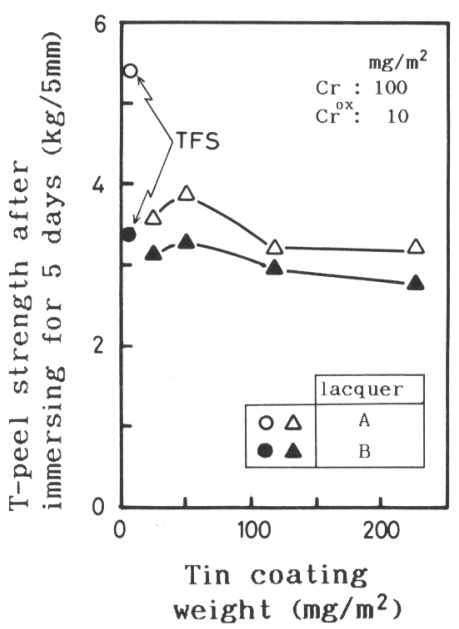

Fig. 8. Effect of tin coating weight on T-peel strength after immersing 5 days in $0.4 \%$ citric acid solution.

も溶接時の温度が低かったことを示している．実際に流 した 2 次電流值で比較しても本供試材の方が低かった. 本供試材の溶接下限電流においてはナゲットが連続して いないが，テアーテストで評価した強度は十分であり， 本供試材の鍛接性が良好であることを示唆している。ま た, ナゲットの出方は TFS-CT に比べると両者ともは るかに均一であった。

\section{$3 \cdot 4$ 塗料密着性}

供試材の塗料密着性は TFS-CT に匹敵するほど優れ ているが, 湿潤下での経時塗料密着性は TFS-CT より 劣っている. Fig. 8 は $0.4 \%$ クエン酸溶液中に 5 日間 経時後の $\mathrm{T}$ ピール強度を示したものであり, 経時密着 
性に優れる TFS-CT と比べると塗料 A では約 $2 \mathrm{~kg} /$ $5 \mathrm{~mm}$ 劣り塗料 B ではほぼ同等の値となった。すず量を 増加させると徐々に経時密着性が劣下寸る傾们がみられ るのは, ぶりきやLTSの Weak boundary layer が, 主 としてすず層とすず酸化膜層の閵であることから理解で きる ${ }^{10)}$. すなわち，すず量の増加と共に䟝離界面が後 処理皮膜一塗料閏が主であったものが，しだいに金属す ずーすず酸化膜閒に移行するようになり経時涂料密着性 が劣るようになったと考えられる。したがって，溶接性 を重視するならばすず哩の多い力が良いが，湿潤下での 経時塗料密着性を重視するならばすず量の少ない方が良 いことになり，用途に忍じて適当な皮膜量を選択するこ とが必要である。

\section{$3 \cdot 5$ 耐食性}

Table 2 に供試材の耐食性試験結果を示した。SST 結果では本供試材の耐錆性はLTSと同程度であり TFS-CTよりやや劣った。この理由は, 金属クロム層 のポアー部分に生成していたクロム水和酸化物の除去が すずめっき時に不十分で，電着すずによるポアーの封孔 が完全でないためと考えられる。また，クロム水和酸化

Table 2. Corrosion resistance of various steel sheets.

\begin{tabular}{|c|c|c|c|c|c|c|}
\hline \multirow[b]{2}{*}{ Specimen } & \multicolumn{3}{|c|}{ Coating weight $\left(\mathrm{mg} / \mathrm{m}^{2}\right)$} & \multirow[b]{2}{*}{$\mathrm{SST}^{*}$} & \multirow[b]{2}{*}{$\begin{array}{l}\mathrm{UCC} \\
\text { test }^{* 2}\end{array}$} & \multirow[b]{2}{*}{$\begin{array}{l}\text { UFC } \\
\text { test }^{* 3}\end{array}$} \\
\hline & $\begin{array}{l}\text { Lower } \\
\text { layer }\end{array}$ & $\begin{array}{c}\text { Middle } \\
\text { layer }\end{array}$ & $\begin{array}{c}\text { Upper } \\
\text { layer } \\
\text { (Chromate) }\end{array}$ & & & \\
\hline $\begin{array}{l}\text { Tin flash-coated } \\
\text { chromium plated } \\
\text { steel sheet }\end{array}$ & $\begin{array}{l}\text { Cr } 50 \\
\text { Cr } 100 \\
\text { Cr } 100\end{array}$ & $\begin{array}{l}\text { Sn } 120 \\
\text { Sn } 120 \\
\text { Sn } 230\end{array}$ & $\begin{array}{l}10 \text { as } \mathrm{Cr} \\
10 \text { as } \mathrm{Cr} \\
10 \text { as } \mathrm{Cr}\end{array}$ & $\begin{array}{l}5 \\
6 \\
6\end{array}$ & $\begin{array}{l}4 \\
5 \\
5\end{array}$ & $\begin{array}{r}120 \\
80 \\
90\end{array}$ \\
\hline Tinplate & Sn 2800 & - & 5 as $\mathrm{Cr}$ & 7 & 5 & 50 \\
\hline LTS & $\mathrm{Ni} 20$ & Sn 800 & 8 as $\mathrm{Cr}$ & 6 & 5 & 120 \\
\hline TFS-CT & $\mathrm{Cr} 100$ & & 15 as $\mathrm{Cr}$ & 7 & 4 & 90 \\
\hline \multicolumn{7}{|c|}{$\begin{aligned} \text { Evaluation }: & * 9(\text { good }) \leftrightarrow 1(\text { poor }) \\
& * 25(\text { good }) \leftrightarrow 1(\text { poor }) \\
& * 3 \text { Delamination area }\left(\mathrm{mm}^{2}\right)\end{aligned}$} \\
\hline
\end{tabular}

物量が TFS-CT よりも若干少ないことも原罒している と考えられる．本供試材の中でも金属クロム量を50 $\mathrm{mg} / \mathrm{m}^{2}$ に減少させると耐錆性が少る倾问がみられた。 金属クロムの被覆率は量の増加と其に们上し，60 $\mathrm{mg} / \mathrm{m}^{2}$ くらいから飽和する傾们にあるが SST 結果の差 はこの原因によるものと考えられる。UCC 試験結果で は，ぶりきはすず溶出型，TFS-CT は鉄溶出型の腐食 形態となるが，本供試材は LTS と间様に金属すずが你 在する期間はすず溶出型であり，金属すず溶解後は鉄溶 出型となるものと考えられる。したがって，霍食形態は TFS-CTに類似しているが鉄浴出量は TFS-CTより 少ない

UFC 試験結果は，本供試材の染料密着性が LTSよ りも良好なことを反映し LTSよりも垦好であった。

Fig. 9(a) は後処理皮膜量と UFC 値の関係をみたもの であり，後処理皮膜量が多いすが艮好であった．Fig. 9 （b）に示すようにUFC 特性はXPS で評価した後処理 皮膜の被覆率と良く対応しており，UFC 試験值に後処 理皮膜の被覆率が大きな影響を及ぼすことを亦してい る.

このように，本供試材の特性が良好なのは本供試材の 皮膜構成が TFS-CTに類似して抢り，さらに，微量の すず層が耐食性に有利に作用するためと考えられる。ま た，内容物としてコーヒーとウーロン茶を旮填後， $37^{\circ} \mathrm{C}$ で 1 年間貯蔵後の鉄溶出量を測䇥したところ，什 内面側を $50 \mathrm{mg} / \mathrm{dm}^{2}$ のエポキシ・フェノール系涂料でシ ングルコートした本供試材と LTSの溶接们は，比較に 使用した午内面側を $100 \mathrm{mg} / \mathrm{dm}^{2}$ のエポキシ・フェノー ル系塗料でダブルコートした TFS-CTの接着行に近い 性能を有していることがわかった。

\section{$3 \cdot 6$ 傷つき性}

Table 3 に製造ラインによる種々の表解処理鋼板の加 熱前後の動摩擦係数を示した. Table 3 の測走値は 2 枚

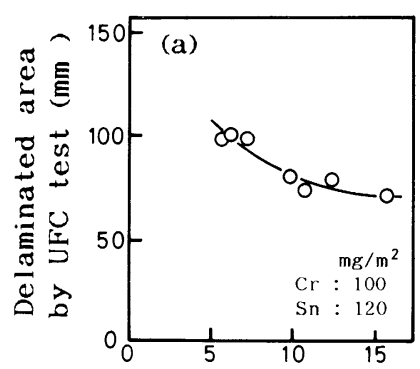

Chromate coating weight $\left(\mathrm{mg} / \mathrm{m}^{2}\right.$ as $\left.\mathrm{Cr}\right)$

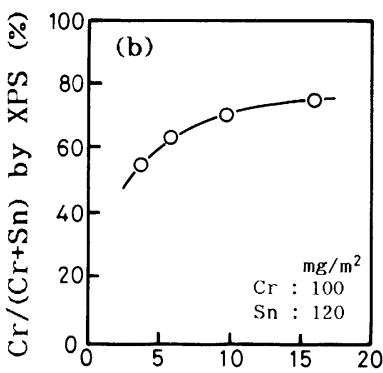

Chromate coating weight $\left(\mathrm{mg} / \mathrm{m}^{2}\right.$ as $\left.\mathrm{Cr}\right)$
Fig. 9. Effect of chromate coating weight on delaminated area by UFC test (a) and coverage of chromate layer (b). 
Table 3. Coefficient of kinetic friction of various steel sheets.

\begin{tabular}{l|c|c}
\hline \multicolumn{1}{c|}{ Specimen } & Before baking & After baking \\
\hline $\begin{array}{l}\text { Tin flash-coated chromium } \\
\text { plated steel sheet }\end{array}$ & 0.23 & 0.34 \\
Tinplate & 0.20 & 0.42 \\
LTS & 0.22 & 0.32 \\
TFS-CT & 0.27 & 0.82 \\
\hline
\end{tabular}

の試料の!延う们をあわせて，辻延方向にサンプルを移 動させた時の値であるが，鋼板の戊延方向と移動方向を 種々変えても扮扮む枚河じ值であった。加熱前では鋼板 表面の塗油層の影響が支配的で試料間の差は小さいが, $210^{\circ} \mathrm{C}$ で $20 \mathrm{~min}$ の加熱後は最表層の油膜が消失し試料 閆の差が顕著となった。すず層の有無により, 動摩擦係 数が 0.3-0.5のグループと 0.8 以上のグループに 2 分 された，TFS-CT はク口ム水和酸化物層の下に柔らか い金属すず層を有していないため, 油膜が無いと極端に 高い值を示した。本供试材, LTS, ぶりきはクロム水 和酸化物層の下の金属すず曾の作用により TFS-CTよ りも動摩擦係数が小さい.したがって,これらの材料の 傷つき性の良好なことが予測されるが，溶接機で 500 们連続製们時の们内外面の傷の状態を観察すると TFS-CT が最も傷がつきやすく，次にぶりきの傷がめ だった。开，本供試材と LTSは午外面側に軽度の傷 が観祭される程度であり，中でも本供試材の耐傷つき性 が良好であった。この違いは，摩擦により剝離するすず 量が, ぶりき, LTS, 本供試材の順に少なくなるため と考えられ，本供試材は什の内面側を無塗装で使用する 用途にも或好な製们性を份する。

\section{4. 結}

\section{言}

0.1-0.2 g/ $\mathrm{m}^{2}$ の微早すず被覆を施したクロムめっき 鋼板について，すずの電着状態，加熱時の鉄一すず合金 化挙動, 溶接性と接触電父抵抗, 酎食性, 塗料密着性お よび傷つき性について，LTS，TFS-CT および 2.8 $\mathrm{g} / \mathrm{m}^{2}$ のぶりきと比較した結果次のことがわかった.

1 ）低濃度すずめっき浴を用いると，水素発生により 金属クロム上のクロム水和酸化物を效率良く除去するこ
とができ，金属クロム上に均一で密着性の良いすずを電 着できる。

2) 金属クロム穈の加熱時の鉄一すず命金化皮応の抑 制作用により，高温，矪時閒焼付塗装時にも多量の金属 すずを残存させることができるため，LTSやぶりきよ りも高温焼付塗装に適していると考えられる。

3 ) 加熱後に $0.1 \mathrm{~g} / \mathrm{m}^{2}$ 以上の金属すずが残存すれば, 金属クロム量や後処理皮膜量によらず低い接触電気抵抗 值が得られる。

4 ）溶接性は $R c$ 值で予想される以上に皮膜量の影響 を強く受ける。溶接部の熱影響の程度から判断すると LTSよりも低温側で接命がおこり，錹接性の良好なこ とが推察される.

5 ) 湿潤下での経時塗料密着性は TFS-CTよりも茯 干劣る。また，すず量の増加により塗料密着性が低下す る傾问がある。

6 ）酎食性は TFS-CT に類似した挙動を示すＳST で評価した酎錆性は TFS-CTよりやや少り，LTSと 同程度である。一方，微量すずが存在することにより染 装後酎食性は TFS-CT よりやや優れている。

7 ）加熱後の傷つき性は LTS，ぶりき，TFS-CTに 比べると最も良好である。

\section{文献}

1) 中小路尚国，緒方 鉄と鋼， 72 (1986), p. 1165

2 ) 盛山博一, 藤本輝則, 斧田一郎, 乾 恒大: 鉄と鋼, 69 (1983), S 1233

3) 吉田光男, 東 光郎, 渡辺 孝, 羽田隆可: 鉄と鋼, 70 (1984), S 323

4 ）渡辺豊文，岩佐浩樹，神原繁雄：鉄と鋼，71（1985）, $\mathrm{S} 1247$

5 ）日本特許公告公報 昭 63-35718 号

6 ）清水信義，国繁文男，藤本輝則: 鉄と鋼，72 (1986), S 1339

7 ) 斧田一郎，盛山博一，河村宏明: 金属表面技術，33 (1982), p. 489

8 ) M. Ichikawa and T. SaITo: Proc. 4th International Tinplate Conference (1988), Paper No. 40 [International Tin Research Institute]

9 ) 宮地昭夫, 安仲健二, 藤村 可, 清水信義: 鉄と鋼, 72 (1986), p. 1149

10）ぶりきとティンフリー・スチール（東洋鋼鈑(株) 編) (1970), p. 178 [アグネ] 